\title{
Dynamics of Rural Urban Water Flows and Implications on Peri-urban Water Security
}

\author{
Anushiya Shrestha, Rajesh Sada and Ashutosh Shukla \\ Peri-urban Water Security Project \\ Nepal Engineering College-Center for Postgraduate Studies, Kathmandu, Nepal \\ e-mail: anushiyas@nec.edu.np
}

\begin{abstract}
The rapid and haphazard urbanization in Kathmandu and expansion of built-up area to the peri-pherial rural landscapes has resulted to formation of peri- urban areas which are now themselves transforming into urban form. Simultaneously, the water being diverted or transferred from these peri-urban areas is rapidly evolving. This paper describes the changing modes of urban oriented water flow from the peri-urban landscape of Kathmandu and the implications of this water transfer on water security of peri-urban areas. Through series of semi-structured interviews, formal and informal discussions with local people and key informant interviews, the study found that Matatirtha, a peri-urban village, has traditionally been a source of water for the domestic water demand in Kathmandu. However, the social and economic developments have induced a paradigm shift in urban water transfer from the area and promoted the economic benefits as a way of compensating the loss of local water resources. Moreover, the increasing opportunities of economic benefits through water in absence of regulatory mechanism have facilitated exploitation of resources. This, therefore, created need of strong mechanism, promoting insights for sustainable management of water resources and contribute to improve rural urban linkages through optimal use of water resources.
\end{abstract}

Key words: peri-urban, urbanization, water transfer modes, water management

\section{Introduction}

Kathmandu valley has been the most urbanized area in the country. The pace of the urban growth in Kathmandu valley has been rapid after 1980 with the increased connectivity of Kathmandu to other parts of the country. Decade-long conflict has caused an increase in rural to urban migration and there has been $61.2 \%$ population growth in Kathmandu in the last decade (CBS 2012). This process of urbanization and subsequent expansion of the built-up area to the peripheral rural landscape has resulted to emergence of rural-urban intermediary. These areas are differentiated by a mixed rural-urban economy and livelihood. Researchers have proposed have various names for these areas; such as peri-urban interface (Allen 2003, Brook et al. 2003, Narain \& Nischal 2007), rural-urban fringe (McMillen 1989, Friedberger 2000) and Desakota (McGee 1991, Moench \& Gyawali 2008). This study has called these as peri-urban areas.
These areas have traditionally been supplier of food and much needed natural resources; land, water, soil and clean air, to sustain urban livelihood and maintain urban ecology. Rapid growth in urban water demand accompanied by this population growth in Kathmandu led to the transfer of water not only from the rural hinterlands, but also from the dynamic peri-urban areas. Kathmandu Upatyaka Khanepani Limited (KUKL), the water service providing agency in Kathmandu, is capable of supplying only 155 and 100 million litres of water per day (MLD) during wet and dry seasons respectively against demand of 320 MLD. Thus a shortage of 165 and 220 MLD in the wet and dry seasons are apparent (KUKL 2010). Figure 1 shows the current status of water supply situation in Kathmandu valley. This situation has forced people to look for other reliable sources of water supply which has led to the emergence of different modes of water flow from peri-urban and rural areas to urban core in 
Kathmandu. This flow is essentially unregulated and spontaneous and has been constantly evolving after 1990 s with the progressively increasing water scarcity in Kathmandu. Moench and Janakarajan (2006) argue that the emergence of different modes of water transfer from rural and peri-urban areas in Kathmandu has been the result of demand for convenient water supply, created by the gap left by the combined services of traditional sources and piped water supply system in Kathmandu Valley.

It is in these realities, this paper tries to discuss the different modes of water flow from rural to urban area with the increasing urban water demand, role of institution to regulate water flow and implication of water flows at local level through the case of Matatirtha Village Development Committee (VDC).

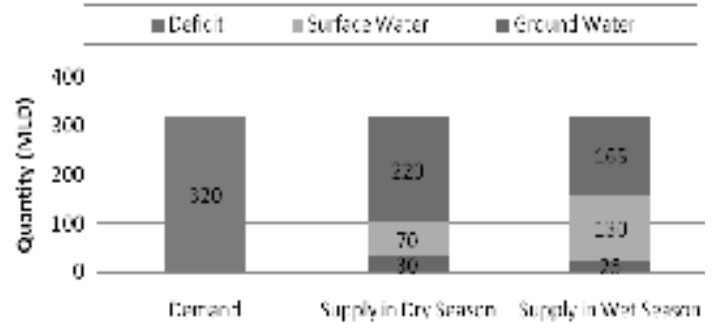

Fig.1. Water demand and supply scenario in Kathmandu valley

(Source: modified from KUKL 2010)

\section{Methodology}

Study Area

This study was carried out in Matatirtha VDC which lies at $85^{\circ} 14^{\prime \prime}$ East and $27^{\circ} 40^{\prime \prime}$ North. It is located at the western part of Kathmandu district and is approximately $5 \mathrm{~km}$ away from the urban area and situated on the lap of Chandragiri hills. The landscape of the VDC is rough and undulating with low to medium agricultural potential. The VDC covers an area of $6.19 \mathrm{~km}^{2}$ and is inhabited by 1413 households, with a total population of 5982 people (2978 female and 3004 male).

Urbanization has been a very recent phenomenon in this VDC starting not more than a decade earlier. The infrastructure development took pace only after 2006 and major increase in population occurred with increasing immigrants after 1999 as a result of decade long civil disturbances in the country. However, though recently started the population expansion and land use change from agriculture to residential purposes has been expanding increasingly across the VDC.

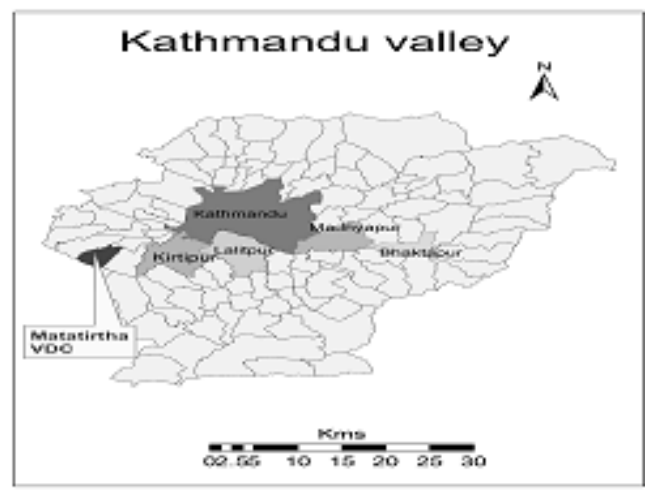

Fig.2. Map of study area

Figure 3 shows the trend of population growth at Matatirtha. The higher population in 1981 could possibility be due to over enumeration as a result of monetary incentive given to the field workers based on head count (Karki 1992 as cited in CBS 2003).

Urbanization has been a very recent phenomenon in this VDC starting not more than a decade earlier. The infrastructure development took pace only after 2006 and major increase in population occurred with increasing immigrants after 1999 as a result of decade long civil disturbances in the country. However, though recently started the population expansion and land use change from agriculture to residential purposes has been expanding increasingly across the VDC.

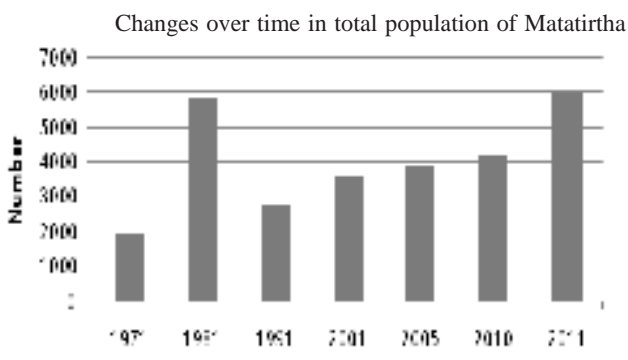

Fig.3. Population trend at Matatirtha

\section{Research Design}

The study is based on qualitative research design involving series of focus group discussions, semistructured interviews with local residents, and direct field observation to capture the information on different modes of water flows from Matatirtha to different areas over the years and their experiences and perceptions on the positive and negative implications of the water transfer in terms of local water security. The information collected were substantiated through discussions with 
key informant's which included the local political leaders, key functionaries of water users committees, water entrepreneurs, government and nongovernmental officials. Secondary sources of data from VDC, CBS and local institutions have been used to validate the findings from the formal and informal interactions.

\section{Results and Discussion}

\section{Changing modes of water transfer}

Matatirtha VDC is well known for its rich water resources endowment in Kathmandu district. It endows three major spring water sources namely, Bhusunkhel or Khwanglang, Luwangkot and Dharapani which have been supplying water not solely for local needs but also to the expanding urban population. The modes of water flow from Matatirtha to different parts of Kathmandu can be classified into three different phases as stated hereunder:

\section{Sharing water as social good}

Generally, water has been considered as a social good in rural areas of Nepal. Considering the principle of water as social good, water has been transferred from rural areas to the different urban parts of Kathmandu Valley. According to the local people, water transfer from Matatirtha started in the ruling period of Rana Prime minister Chandra Shamsher. Drinking water was supplied from the Bhusunkhel spring source to major parts of today's Lalitpur Sub-Metropolis and Kirtipur Municipality. After 1948, due to the increasing water scarcity within the VDC, water supply to Lalitpur was stopped while the supply to Kirtipur was stopped only 3 or 4 years ago. Drinking water supply from this VDC to adjoining Satungal VDC began in 1968. This traditional mode of rural to urban water supply in Matatirtha was driven by the social value associated with water considering water as social good and thus serving this precious resource was considered an auspicious activity. Supply of water to the neighboring Naikap and Tinthana VDCs also started with the same social motive and traditional understanding.

\section{Harnessing water as social and economic good}

With increasing urbanization, there have been changes in the historical modes of water supply system from Matatirtha to the neighboring VDCs.

Table 1. VDCs with water supplied from Matatirtha and revenue collection

\begin{tabular}{l|l|l|l|l|l}
\hline S.N & $\begin{array}{l}\text { Name of VDC with } \\
\text { supplied water }\end{array}$ & Starting year & $\begin{array}{l}\text { Revenue } \\
\text { collected } \\
\text { (NPR) }\end{array}$ & $\begin{array}{l}\text { Volume of water } \\
\text { suphied (inch) }\end{array}$ & $\begin{array}{l}\text { Use of collected } \\
\text { revenue }\end{array}$ \\
\hline 1 & Satungal & 1968 & Free supply & 4 & - \\
2 & New Naikap & 2002 & $600000-$ & 1 & Piped Water Supply \\
3 & Tinthana & 2010 & $360000-$ & 1.5 & $\begin{array}{l}\text { Piped Water Supply } \\
\text { Piped Water supply }\end{array}$ \\
\hline
\end{tabular}

Satungal, being the major exit for Matatirtha to the urban area, the historical mode of free water supply has been continued as an exchange to the need of Matatirtha to use of road along Satungal.

Water supply to Tinthana and Naikap which started with the same traditional value has undergone change from water as a social good to economic good. The local government at Matatirtha in co-ordination with the Spring Conservation Committee, an independent committee functioning in the Matatirtha, has started collection of revenue for the provided water services to these VDCs since 2002 (Table 1).
The revenues thus generated through the harness of water resources have been used for construction of basic infrastructures within the VDC, allocating a major portion of it for initiating and expanding the piped water supply in different parts of Matatirtha.

In addition to the neighboring VDCs, rich water resource in Matatirtha has also been an attraction for the several urban oriented water based industries. There are 12 other industries of different scales operating in this VDC.

These include foot wear industry, Plastic industry, dying industries and hotel and resorts. Local 
government has been collecting revenue from urban oriented water based industries functioning in Matatirtha which as per VDC profile 2010 amount to an annual revenue of around NPR. 200,000.

Highland distillery established in the year 1993 has been diverting water from Bhusunkhel spring for its water needs and is the highest tax payer with around NPR.70,000 per year. These urban oriented water based industries have been an income source for the local government of Matatirtha. However, under the influence of power and politics, the local administration has not been able to enforce the tax. Thus, the current income has been much lower than the potential income for the VDC.

The creation of employment opportunity in the growing industries has been a major benefit perceived by local people, both male and female in Matatirtha. This has been a better attraction over the traditional agricultural based livelihood in this hilly VDC. According to the local people, this new sector of income has been a cause of growing shortage of labor for agricultural activities in the VDC. Over the years, local people in the VDC have been demanding for the need of increasing engagement of local people over the labor from other areas.

\section{Transferring water as commercial good}

According to Shrestha (2011), water transfer from this village to quench the thirst of urban dwellers was started in 1996 whereas water market in Kathmandu has started since late 1980s and gained its momentum after 1990. The private water supply service in Matatirtha started in the same period through Sunshine Beverage owned by a local water entrepreneur and there has been no cessation for this business since then.

The water entrepreneurs operating in Matatirtha have been extracting water either from springs originating in the privately owned land or by installing shallow or deep tube wells in privately owned or leased-in lands (Fig. 3). Besides, water entrepreneurs with power reach have also been diverting water from public springs for commercial water supply. The water in the form of bottled water or tanker water supply is either directly supplied to the consumers or sold to the water tanker intermediaries who own tankers but do not own water source. These tanker intermediaries either supply the purchased tanker water directly to the consumers or further operate their bottling water industries based on the purchased water.

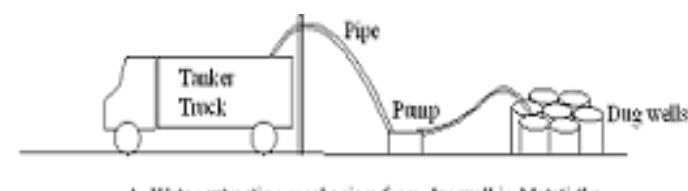

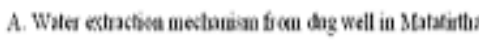

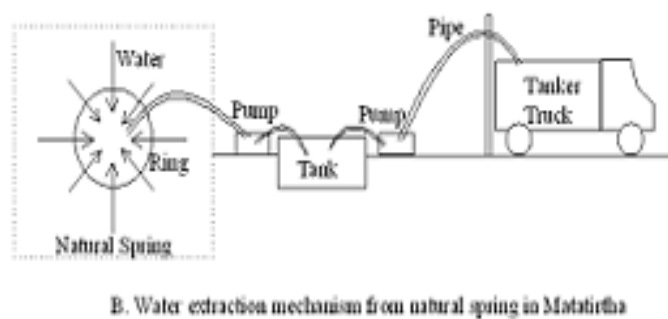

Fig. 4. Water extraction mechanism at Matatirtha (Source: Shrestha 2011)

The study found 14 water extraction points in the village (Table 2) which include wells and springs in private land, spring in public land and one is from deep boring. A total of 35 tankers of varying sizes (5000, $7000,8000,10000$ and 12000 litres) have been transferring water to urban areas from this village (Fig. 4). Thirty two of these are owned by water entrepreneurs within VDC whereas three belong to entrepreneurs from outside. Additionally, ten water bottling industries are being operated. According to Matatirtha VDC profile 2010, around 170 trips of water supply by water tanker that approximates to 1.2 million litres of water, is supplied to different places of the Kathmandu metropolis as well as to other parts of Kathmandu valley on a daily basis. The public service centers such as bus parks, hotels in the city where there is huge demand of water, the residential areas in Balaju, Thamel, New Road, Baneshwor and Kalanki are considered as the major consumers by the water entrepreneurs based in Matatirtha.

The price of a tanker of water is on average NRs. 1,500 for the tanker size of 6,000 litres and NPR. 2,500 for the tanker size of 12,000 litres. Once the water reaches to the city, water is sold even at higher costs for those demanding smaller volume of water for domestic needs. In the cases, where a farmer leases out the land for water extraction, each farmer is paid NPR. 200 for every 6,000 litres and NPR. 400 for every 12,000 litres tanker filled. Currently, all the interest has been in earning 
Anushiya Shrestha et al./Dynamics of Rural Urban ......

income from the rich groundwater and spring sources from the area without any concern for groundwater recharge and springs protection for sustainable water use. Water business in Matatirtha has been a good source of earning for the land owners with high groundwater table and the water entrepreneurs involved in the operation of water tanker. Furthermore, the growing water business in Matatirtha has also been an attractive income source for the entrepreneurs from different parts of Kathmandu, mostly those in the neighboring VDCs mainly Satungal, Machhegaun, Tinthana, Kirtipur, Dhungeadda. These entrepreneurs from outside the VDC have been engaged in the commercial water business through partnership with the local water entrepreneurs.

Table 2. Water extraction points at Matatirtha

\begin{tabular}{|c|c|c|c|c|}
\hline S.N & Name & Latiitude & Longitude & $\begin{array}{l}\text { Years of } \\
\text { initiation }\end{array}$ \\
\hline \multirow[t]{3}{*}{1} & $\begin{array}{l}\text { Sunshine Beverage (Dela Mineral Water Bottling' } \\
\text { Matatirtha Khanepani Tanker)* }\end{array}$ & $27^{\circ} 40^{\prime} 31.8^{\prime \prime}$ & $85^{\circ} 13^{\prime} 27.4^{\prime \prime}$ & 2000 \\
\hline & $\begin{array}{l}\text { Duwa Food Products and Beverage Water Bottling/ } \\
\text { Machhe narayan Tarker Water* }\end{array}$ & $27^{\circ} 40^{\prime} 36.6^{\prime \prime}$ & $85^{\circ} 14^{\prime} 27.9^{\prime \prime}$ & 2001 \\
\hline & Natural Matairtha Khanepani Pvt Ltd* & $27^{\circ} 40^{\prime} 36.2^{\prime \prime}$ & $85^{\circ} 1429.6^{\prime \prime}$ & 2008 \\
\hline 2 & Alpine Spring Mineral Water & $27^{\circ} 40^{\prime} 35.4^{\prime \prime}$ & $85^{\circ} 1424.6^{\prime \prime}$ & 2008 \\
\hline 3 & Himal Mineral Water Udyog & $27^{\circ} 40^{\prime} 37.0^{\prime \prime}$ & $85^{\circ} 1425.4^{\prime \prime}$ & 2009 \\
\hline 4 & Himsikhar Khanepani & $27^{\circ} 40^{\prime} 37.3^{\prime \prime}$ & $85^{\circ} 14^{\prime} 33.2^{\prime \prime}$ & 2009 \\
\hline 5 & Shree Ganesh Khane pari & $27^{\circ} 40^{\prime} 37.4^{\prime \prime}$ & $85^{\circ} 1422.8^{\prime \prime}$ & 2009 \\
\hline 6 & 24 Carat Spring Mineral Water (Public spring) & $27^{\circ} 40^{\prime} 36.5^{\prime \prime}$ & $85^{\circ} 1432.7^{\prime \prime}$ & 2009 \\
\hline 7 & Nepal Khanepani (cormue rcial de ep boring) & $27^{\circ} 40^{\prime} 36.0^{\prime \prime}$ & $85^{\circ} 1418.1 "$ & 2010 \\
\hline 8 & Gud Khanepani & $27^{\circ} 40^{\prime} 29.5^{\prime \prime}$ & $85^{\circ} 1436.5^{\prime \prime}$ & 2008 \\
\hline 9 & New Matatirtha Khanepani & $27^{\circ} 40^{\prime} 37.6^{\prime \prime}$ & $85^{\circ} 13^{\prime} 33.8^{\prime \prime}$ & 2008 \\
\hline 10 & Prakash Khanepani & $27^{\circ} 40^{\prime} 35.9^{\prime \prime}$ & $85^{\circ} 14^{\prime} 31.8^{\prime \prime}$ & 2007 \\
\hline 11 & Gopal Khane pani Matatirtha & $27^{\circ} 40^{\prime} 36.5^{\prime \prime}$ & $85^{\circ} 1427.1^{\prime \prime}$ & 2006 \\
\hline 12 & Jiwanta Khanepani & $27^{\circ} 40^{\prime} 35.6^{\prime \prime}$ & $85^{\circ} 1425.2 "$ & 2009 \\
\hline 13 & Ganesh Khanepari & $27^{\circ} 40^{\prime} 37.6^{\prime \prime}$ & $85^{\circ} 1423.2^{\prime \prime}$ & 2008 \\
\hline \multirow[t]{2}{*}{14} & Harru Mine ral Water & $27^{\circ} 40^{\prime} 37.3^{\prime \prime}$ & $85^{\circ} 1421.8^{\prime \prime}$ & 2010 \\
\hline & \multicolumn{4}{|c|}{$\begin{array}{l}\text { *= spring in private land } 1^{\text {st }}-7^{\text {th }} \text { own both tarker and bottling industry, } \\
8^{\text {th }}-13^{\text {th }} \text { are only corrume rcial water extraction points and neither own tanker nor bottling industry and } 14^{\text {th }} \\
\text { owns bottling industry but doesn't own tanker) }\end{array}$} \\
\hline
\end{tabular}

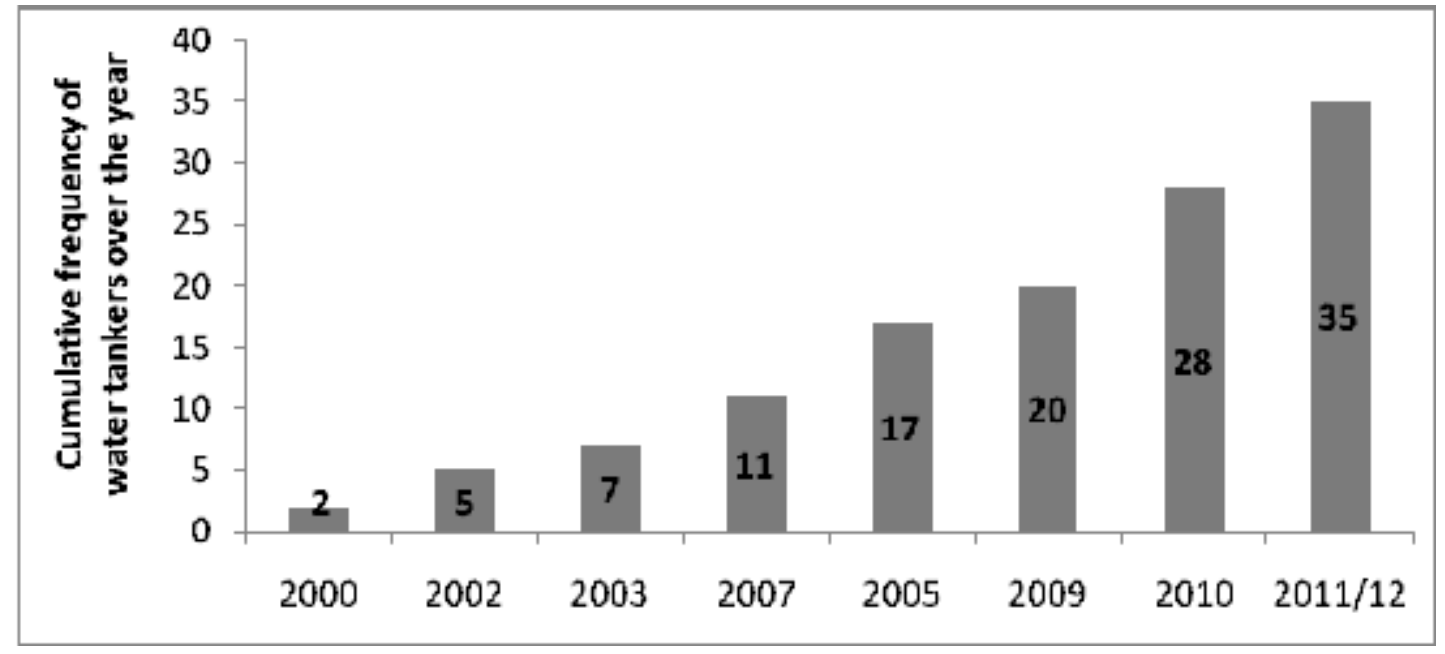

Fig. 5. Growing trend of private water tankers operated in Matatirtha 


\section{Implications of rural urban water transfer on local water supply}

The household water management in the past decades was real hardship primarily for women in Matatirtha while agriculture has mainly remained rain-fed in this hilly VDC. Currently, eight different communities based water supply schemes are functional in Matatirtha for domestic water supply. Seven of these water supply schemes have been tapping water from three major springs while one is based on the ground water extracted from deep boring. Among these, seven schemes have been supplying water through private taps, only Dharapani Khanepani has been serving through public taps. A part of the investment for these community water supply schemes serving water to the local people have been managed through revenue generated from the water services provided to neighboring VDCs.

While the local people appreciate the water service provided by the community water supply service, with increasing urbanization, the increasing competition over the water resource for domestic, industrial and commercial purposes has been their growing concern. The hours of water supply available from the eight community water schemes have been declining over the years. There has been growing realization and acceptance among the households that constraints to water supply would increase in future than what people in the area have been facing at present. The adaptive strategies of the households have been obtaining private connection instead of depending on public stand posts and digging private wells and constructing large sized underground water tank or roof top water storage tanks to meet the water needs for a number of days. Similarly, getting connection to more than one water supply schemes for future water security has been another interesting practice in the area. This is essentially a planned adaptation to the possible shortage of water in future.

The local people have perceived this primarily as the consequence of massive extraction of water for the commercial urban water supply and growing commercial activities within the VDC along with the increasing water demand at the households. Though documentation on the water extraction from the area has not yet been available, the current water abstraction in the VDC is more apparent to be higher than the critical abstraction rate. Excessive and unbalanced extraction of water resource has brought concerns among the people with regards to the sustainability of the water resource in the area. This has raised question about the prior-appropriation water right, equity issues, water insecurity and vulnerability of these communities in the context of increasing urbanization.

\section{Role of local government as a regulatory body}

Local government and other local actors are best placed to identify local needs and priorities and provide an adequate response to them. Local decision-making, supported by adequate resources can support positive rural-urban linkages (Tacoli 2003). Activating the Local Self Governance Act-1999, that empowers VDC office as the custodian of natural resources within the VDC, Matatirtha VDC spearheaded to regulate the exploitation of water resource in Matatirtha. Through an agreement among the water entrepreneurs, VDC officials and local people, guidelines for regulating the commercial water extraction (both water tankers and bottling industries) operating in the village were drafted and VDC officially initiated licensing process as a means of regulating the rampant water extraction and was envisioned to be enforced starting from $16^{\text {th }}$ July 2009.

The agreement restricted the use water sources for commercial purposes without the permission of the VDC office. It also prohibited the water extraction through deep boring and restricts the water entrepreneurs to dig wells with depth exceeding 30 feet. The VDC enforced a levy of NRs. 10,000 per year from the water bottling industries and NRs. 1,000 for small tanker per month and NRs. 1,200 for large tanker per month. The agreement also laid out terms and conditions concerning the protection of the local environment and the water sources and frameworks for conflict resolution holding the right to prohibit water business in case of drought or natural hazards in the area.

While the water entrepreneurs in the VDC claimed to have provided employment service to local people, the local people felt the existence of employment opportunity in bottling industries and however considered tanker water supply to be over exploiting of resources increasing the threat of water insecurity 
in the near future. Considering this, the VDC office imposed restriction on the water tanker entrepreneurs and put a limit on the volume of water extraction from the VDC whereas promoted water bottling industries expecting to create employment opportunities for the people, particularly the women, at the local level.

This was a commendable effort by the local government to stop the exploitation of the water resource while continuing the benefits from the harness of available water resources through monitored water business. However, having water entrepreneurs with economical, social and political power reach, the attempt of regulating the commercial water extraction within the VDC is hardly implemented. While the water entrepreneurs have been claiming themselves to have been legalized through registration provided by Valley Water Supply Tanker Entrepreneurs Association and Water Bottling Association, the local government has still not approved this mechanism and has been lobbying for the regulatory agreement made at the local level. Currently, the agreement has been dissolved. Though VDC officials have been working for the reorientation in regulating increasing water exploitation, so far no major achievement has been made for future water security in Matatirtha.

\section{Growing grievances towards free water supply to Satungal}

Free water supply to Satungal VDC has been a prime reason put forward by the water entrepreneurs in Matatirtha for not paying the levy imposed by the local government. As per the local people, the traditionally established water supply mechanism to Satungal diverted only one inch of water yield from Bhusunkhel spring located at Matatirtha. With increasing water demand in Satungal, the diversion was increased to two inches around a decade ago. Around five years back with establishment of Dhaulagiri Residential Complex in Satungal, the water supply was further increased to four inches. The local people of Matatirtha claim that Satugal VDC has been making money out of free water service provided by Matatirtha by collecting a water tarrif/ water service charge for supplying water through household piped connection to the households of Satungal.

The next dissatisfaction of the local people of Matatirtha is that they have pay road tax to Satungal VDC while Satungal VDC has been enjoying free water service from Matatirtha. Though in past the exit through Satungal was tax free, after the constitution of Satungal-Matatirtha Road Consumers Committee in 2003, it has been collecting tax from vehicles plying along the road. This gradually generated grievances among the Matatirtha residents. There has been growing dissatisfaction about the exchange of services (water services and the road services) among the two neighboring VDCs with one continuing to provide free service while other increasingly charging road tax.

The water entrepreneurs have been completely against the free water supply to Satungal and considered the need of bringing Satungal VDC under tax before the local authority implements any regulation to control water market operated by local people of Matatirtha itself. Local authority at Matatirtha however has not made any attempt towards changing the traditional mode of water supply to Satungal envisioning the likely impacts of disturbance in the historical community relation.

The findings of the study shows rapid population growth and urbanization accompanied by escalating urban water demand is increasing water transfer from rural and peri-urban areas to urban areas. Not only urban areas but peri-urban areas like Matatirtha VDC is also facing rapid population growth resulting in increase in water demand within the village itself. Simultaneously, the social and economic developments have induced a paradigm shift in urban water transfer from this peri-urban area, promoting the economic benefits as a way of compensating the loss of local water resources. Moreover in the absence of regulatory mechanism, the increasing opportunity of economic benefits through water business has facilitated exploitation of resources. The widespread extraction of water resources discarding the likely impact on the sustainability of the resource has raised a growing concern for the local water security however the attempt of local government to regulate the water exploitation has not been successful. The findings suggest the need of exploring ways for sustainable management of water resources and promote the rural urban linkages created through water.

\section{Acknowledgements}

The paper is based on the findings of action research project on Water Security in Peri-urban South Asia: 
Adapting to Climate Change and Urbanization, implemented in peri-urban areas of Kathmandu Valley by Nepal Engineering College in coordination with South Asia Consortium for Interdisciplinary Water Resource Studies (SaciWATERs) with financial support of International Development Research Centre (IDRC), Canada.

\section{References}

Allen, A. 2003. Environmental planning and management of the peri-urban Interface: Perspectives on an emerging field. Environment and Urbanization 15 (1): 135-147.

Brook, R., S. Purushothoman and C. Hunshal (Eds.). 2003. Changing frontiers: The peri-urban interface HubliDharwad, India. Books for Change, Bangalore. $146 \mathrm{pp}$.

CBS. 1971. Population census. Central Bureau of Statistics, HMG, Nepal.

CBS. 1981. Population census. Central Bureau of Statistics, HMG, Nepal.

CBS. 1991. Population census. Central Bureau of Statistics, HMG, Nepal.

CBS. 2001. Statistical year book of Nepal. Kathmandu. Central Bureau of Statistics, HMG, Nepal.

CBS. 2003. Population monograph of Nepal. Vol. 1. Population size, growth and distribution. 37-86. Central Bureau of Statistics, HMG, Nepal.

CBS. 2012. National population and housing census (Village Development Committee/Municipality). Central Bureau of Statistics, Government of Nepal, Kathmandu, Nepal.

Friedberger, M. 2000. The rural-urban fringe in the late twentieth century. Agriultural. History 74 (2): 502-514.

Karki, Y. B. 1992. Estimates and projections of population, Nepal: 1981-2031. Central Department of Population Studies, Tribhuvan University, Kathmandu, Nepal.
KUKL. 2010. KUKL at a glance. Third Anniversary. Kathmandu Upatyaka Khanepani Limited (KUKL), Kathmandu, Nepal

McGee, T. G. 1991. The emergence of desakota regions in Asia: Expanding a hypothesis. 3-26. In Ginsburg N., Koppel B. and McGee, T. (Eds.) The extended metropolis: Settlement transition in Asia. University of Hawaii Press, Honolulu.

McMillen, D. P. 1989. An empirical model of urban fringe land use. Land Economics 65 (2): 138-145.

Moench, M. and D. Gyawali. 2008 Desakota: Reinterpreting the Urban-Rural Continuum. Retrieved from http:// www.espa.ac.uk/files/espa/ Final\%20Report $\% 20$ Desakota\%20_Part\%20II\%20A\%20Reinterpreting\% 20Urban\%20Rural\%_20continuum_0.pdf

Moench, M. and S. Janakarajan. 2006. Water markets, commodity chains and the value of water. Water Nepal 12 (1): 81-114.

Narain, V. and S. Nischal. 2007. The peri-urban interface in Shahpur Khurd and Karnera, India, Environment and Urbanization 19 (1): 261-273

Shrestha, D. 2011. State and services of private water tanker operation in Kathmandu. Master thesis. Pokhara University. Nepal Engineering College-Center for Postgraduate Studies, Kumari Club, Kathmandu, Nepal.

Sullivan, W. C., O. M. Anderson and S.T. Lovell. 2004. Agricultural buffers at the rural-urban fringe: An examination of approval by farmers, residents, and academics in the Midwestern United States. Landscape and Urban Planning 69: 299-313.

Tacoli, C. 2003. The links between urban and rural development. Environment and Urbanization 15 (1).

VDC. 2005. Matatirtha village development committee profile. Kathmandu, Nepal.

VDC. 2010. Matatirtha village development committee profile. Kathmandu, Nepal. 